Running head: DENIAL OF RELEVANCE

\title{
The Denial of Relevance: Avoidance, Awakening, \& Guidance
}

\author{
Van VanBebber \\ University of North Texas
}

\begin{abstract}
Author Note
Van VanBebber, PhD ABD, JD, MS, College of Information, University of North Texas.
\end{abstract}




\begin{abstract}
Addresses information-avoidance behaviors in relation to religious issues and relates decision-making processes to a proposed protocol for information science professionals who stand better to navigate a range of socioeconomic issues. Articulates interdisciplinary interweaving and overlap of information science and religion, utilizing disciplines of literature, philosophy, theology, and socioeconomics. Explores pragmatic yet spiritual ways of overcoming information denial, cognitive dissonance, and avoidance behaviors.
\end{abstract}

Keywords: information processing, information seeking, information avoidance, seeking behaviors, religious information

\title{
The Denial of Relevance: Avoidance, Awakening, \& Guidance
}

The Nineteenth Century shines brightly upon the Twenty-first Century's call for research of information and religion to gain spiritual knowledge. American author Henry David Thoreau (1854/1992) observed that The mass of men lead lives of quiet desperation" (7), and he sought to awaken" his neighbors. Across the Atlantic, English Cardinal John Henry Newman (1868) asserted, Many... refuse to be awakened, and think their happiness consists in continuing as they are" (58). T.S. Eliot heralded the perennial questions we find persistent each day: Where is the Life we have lost in living? Where is the wisdom we have lost in knowledge? Where is the knowledge we have lost in information?" (5). Such observations reveal what is true of modern humanity: we face an information need for solution or awakening to fulfill potential, to encounter information essential to well-being, and to identify and achieve our dreams. 


\section{DENIAL OF RELEVANCE}

My interdisciplinary approach to - Intersections of interests in the study of information and religion, where different disciplines might find it worthwhile to collaborate in research,” employs a holistic" and "heuristic" (O`Connor \& Copeland, 2003, 95, 102, 113) framework among -epistemological priorities" (97, 140). It presents an analysis embracing the arts, literature, economics, neuroscience, philosophy, theology, and interdisciplinary information science. These disciplines, though seemingly disparate in concern, fill information gaps in the human mind. I contend that religious issues are conducive to information-science analysis, particularly due to their metaphysical nature and potential use in addressing information-avoidance behaviors. That pairing of ideasencompassing this variety of informational sources - may better equip humanity to overcome the quiet desperation" evoked by Thoreau and to respond to Eliot's query, Where is the Life we have lost in living? ... Where is the knowledge we have lost in information?"

Information users today may benefit from an integrated outlook on theology and information to overcome concerns relating to denial, cognitive dissonance, and avoidance behaviors. To that end, I also relate decision-making processes to research of information-science professionals who stand better to navigate a broad expanse of socioeconomic issues. The destination of this voyage will be a pragmatic yet spiritual way of wrestling with information denial and charting the currents of perplexing choice and decision. Reflecting this approach, New York Times columnist David Brooks (2011, March 13) described the theme of his book The Social Animal" (2011):

Yet while we are trapped within this amputated view of human nature, a richer and deeper view is coming back into view. It is being brought to us by researchers across an array of diverse fields: neuroscience, psychology, sociology, behavioral economics and so on.... The conscious mind 


\section{DENIAL OF RELEVANCE}

hungers for money and success, but the unconscious mind hungers for those moments of transcendence when the skull line falls away and we are lost in love for another, the challenge of a task or the love of God. Some people seem to experience this drive more powerfully than others (4P).

\section{Information Question}

The academic literature suggests that information-seeking behaviors become more of a groping than a hunting approach when dealing with broad, high-level decisionmaking on major (and often abstract) life choices. Data from today's culture suggest that dissatisfaction with jobs, finances, and life in general, if not outright anxiety, affects those seeking behaviors. Philosophy and literature may help to better identify and address certain issues, and in combination with the academic literature, may intimate partial causes for behavioral dislocations as well as potential solutions for their resolution. Thus, we may ask, - Can information ultimately help information users find the way back to life?"

Eliot (1962) described the inevitable scenario every information user encounters at some point in life: Footfalls echo in the memory, Down the passage which we did not take, Towards the door we never opened, into the rose-garden" (117). Thus, another way to pose the research question may be stated: Can information be used to increase the probabilities of reaching the rose garden" of an information need?

Thoreau presents to us the condition of -quiet desperation" faced by decision makers today as a characteristic in human nature that contributes to how and whether information users satisfy essential information needs. What causes quiet desperation" and what information may clarify, resolve, or help us understand its relation to individual lives? Thoreau then implicitly poses an informational model (simplify, reduce encumbrances, attend to meaning and purpose [e.g., spirituality]), consistent with what 


\section{DENIAL OF RELEVANCE}

contemporary scholars in Information Science propose as a workable solution to resolving informational behavior problems in satisfying informational needs. Merely encountering Thoreau and Eliot may awaken an anomalous state, possibly latent but existent in the interstices of consciousness and the subconscious.

\section{Information Science Analysis: The Seeking Model}

Early IS scholars proposed a role for information professionals - the core of this proposal - as interactive guides to and through ostensibly disparate information sources. Bush (1945) foresaw trailblazers to establish informational paths through the maze of accumulating information, and Saracevic (1999) noted the interdisciplinary nature of IS because of the nature of the problems it addresses. Bates (1999) described IS as cutting across or orthogonal to content disciplines, as a meta-discipline. Wilson (1977) imagined a new professional: an information doctor aims . . . at making prescriptions, at recommending effective techniques for attaining one's goals.... In effect, he tries to put himself in a position to be able to say, Take this, and you'll find that good things happen to you" (118-119).

Information users are often viewed in the literature on fuman informationseeking behaviors” as active seekers (O‘Connor \& Copeland, 2003, 1; Case, 2002). This assumption can lead to a more linear analysis, which has occasioned much research (3). Additional analyses implicate at least two alternative views on how information users may encounter information needs, gaps, unresolved issues, and question states. The first view has garnered some recent study under the rubric of information avoidance or denial. Seeking or denying information may involve a more active or intentional element. The second analysis invokes a less active and more abstract, nebulous, and 


\section{DENIAL OF RELEVANCE}

vague sense of the entire information-behavioral process, from awareness of the question state itself to the remedy or solution of the information gap. As a result, it conjures a non-linear, messy," and -nondeterministic" analysis $(3,4)$ to reflect how humans may actually be less cognizant of a question, struggle to become aware of and to grasp and comprehend it, wrestle and grapple" with it to evaluate its situational and/or immediate relevance, and grope and -stumble" $(1,100)$ toward resolution.

Information is typically defined broadly to mean -any difference that makes a difference to a conscious, human mind" (Case, 2002, 40). Uncertainty reduction may be viewed as seeking that is motivated by an anomalous state of knowledge" or ASK (74). Information may increase or reduce uncertainty and anxiety, may stimulate and entertain, and may not even be sought - including accidental or incidental information encounters - yet may trigger interest (Id.). There has been a move toward a subjective characterization of relevance, commonly called -situational relevance" (Case, 2002, 95), which Patrick Wilson described as $\longrightarrow$ ] $]$ hatever information solves the particular problem at a particular moment for a particular individual is relevant for that person in that situation” (O‘Connor \& Copeland, 118).

Case, Andrews, Johnson, and Allard (2005) address the history of, and intricacies about, avoidance behaviors. Since Aristotle, scholars have assumed that the impetus to information seeking is a human desire to know, and that information reduces uncertainty. However, humans may seek information congruent or consistent with prior knowledge and beliefs and avoid exposure to information that conflicts with those internal states, hence cognitive dissonance (Id.). Nor does the receipt of information necessarily change attitudes or behaviors, and differences occur in how users may 


\section{DENIAL OF RELEVANCE}

interpret the same information due to their perceptions, memory, motives, and attitudes (Case, 2002). O`Connor, Kearns, and Anderson (2008) similarly describe this phenomenon as a person's — tonplate of understanding” (18). People assess threatening messages based on certain factors: the nature of the hazard, their perceptions of the effectiveness of responses to the threat (response efficacy), and their beliefs about their own ability to achieve effective responses (self-efficacy) (Case et al., 2005).

In any event, scholars confirm the significance of avoidance behaviors: Beyond obsessions, curiosity, and creativity, lies a host of motivations not to seek information" (Case et al., 2005, 354); โT]he idea of avoiding information is rarely discussed" (355$356)$; [W] may neglect or avoid information that is of concern but of no interest" (Wilson, 1973, 465); People can, and frequently do, engage in information avoidance" (Allen, 1996, 119); -Motspeople engage in a combination of information-seeking and information-avoiding behaviors" (12).

Moving beyond the seeking and avoiding behaviors, scholars address another reality of the human thought process — the nondeterministic manner in which humans often solve problems" (O‘Connor \& Copeland, 2003, 3). As part of this reality, a need exists for fumerous sources of assistance in seeking," which may point the way," particularly due to the *ague and iterative nature of many searches" (5). Thus, an overly rigid or linear approach of typical systems may nonsensically compel the user to Tell us what you don't know - and do it in system terms" (6). This challenge is further compounded because the information is not simply waiting to be found" (45). In this eonstant juggling, this constant interplay ... looking for that little anomaly...that does not make sense," the information user can confront insurmountable difficulty when 


\section{DENIAL OF RELEVANCE}

relevant information is not noticed by anyone else, not even visible sometimes to anybody else" (40). Further, in assisting the user, we cannot anticipate all the ways in which people will ask for" relevant information, so the approach should be $[\mathrm{t}]$ olerant of ambiguity, uncertainty, conceptualizing, pragmatic, and visual" concepts (11) to better address the whole human engagement with the lived world and the spectrum of questions and seeking patterns that constitute the means of navigating within that world" (10). Rather than merely placating the need, or accomplishing absolute certainty of a fit" of information to fill a gap or need (6-7), an information professional may usefully narrow or ameliorate the vague need or abstract question state underlying a sense of uncertainty.

Life, or a living being, is equipped with at least a measure of -some reasonably successful set of adaptations for survival in a complex and diverse environment" (2). Imagining there are at least some temporary periods or situations in which a relative status quo exists can be itself susceptible to denial, especially in that —stukness" within the broader range of human thinking modalities [that] has become legitimate" (6). A quintessential paradox of life arises: that which may enable us to avoid demise and even to adapt can also confine us to a narrowly-restrained rut of mediocre and shallow existence, as well as superficial thinking. Amidst this context lies the overall condition of łuman search frailty," yielding a discipline devoted largely to assisting human information seeking" (6).

The reality of human searching involves a paradox" of mistaking -our abstractions for concrete realities" $(98,114)$. As a result, humans seem to wear blinders when information may be -encealed" and various forms of -dissonance" exist (98, 


\section{DENIAL OF RELEVANCE}

110). An epistemological model [should be] hospitable to ambiguity, respectful of failures, and aware that passions are full partners of reason emerged," which acknowledge that seeking strategies move away from the well-articulated look-upquestion state...to see more complex, contingent iterative, and collaborativeseeking behavior" (140). Humans meet a kaleidoscope of potential realities, any of which can be readily evoked by altering the ways in which observations are framed and categorized" $(16,108)$. Framing" is a means of bringing together insights and theories that would otherwise remain scattered in other disciplines" (15), and -Counterframing" then suggests -alternative ways of thinking about their research engagement, and, perhaps more important, they can provide alternative perspectives for viewing problem definition, interpretation, and solution in any given research inquiry" (17). In this way, the information professional may assist not merely in addressing human frailty, but also the coincident fruit of unproductive itlusions" $(20,115)$.

Neuroscience places this process in context. It suggests that reason may not be as pure as most of us think it is or wish it were, that emotions and feelings may not be intruders in the bastion of reason at all; they may be enmeshed in its networks for better or worse.... People who succeed in an information economy are alert and adaptable to an ever-changing environment" (138). The cognitive processes of the brain are recurring loop mechanisms by which sensory data enter, and in which discriminating functions partition vectors to distinguish, for example, different faces and sounds, apples from oranges, through constructed networks of parallel distributed processing" (or PDP") (Churchland, 1995, 11) by *ector coding” and processing $(26,29,35,92)$. New sensory data enter, and the brain partitions the different vectors by -discriminating" among those 


\section{DENIAL OF RELEVANCE}

data $(125,211,236)$. With a new idea, the brain compares it to existing vectors and creates a newly partitioned vector (278). Ereativity ... is probably not a single feature or a one-dimensional phenomenon. ... It is the capacity to see or interpret a problematic phenomenon" (278), for the novel deployment and extension of existing activational prototypes" (279), and then -a human is in a position to find new and surprising applications of those prototypes" (279-280).

If denial or unawareness is implicated, finding such applications may be aided by mentors" (O`Connor \& Copeland, 2003, 146) or tutors who consider the background of the user and their specific needs and situation. $[\mathrm{A}]$ personal rather than impersonal approach [ - ] yielding information selected on the basis of logical relations to our concerns rather than on the basis of subject matter, taking into account one's state of knowledge, perhaps operating in a tutorial' mode, modifying or reformulating information so as to be comprehensible and acceptable to us [- ] would be of enormous power and utility" (Wilson, 1973, 468). Improving human performance may occur by activities to improve the clarity, relevance, and timeliness of the data designed to inform people. . . [and to] try to make them simpler and clearer, thus easier to understand without extensive training [because] redesigning the data will nearly always make the training simpler and easier to achieve" (Gilbert, 1978, 175). This approach may mitigate trepidation in dealing with certain information or in making particularly difficult decisions involving a complex mix of almost infinite variables, which may not be fully capable of articulation by the person with the information need or question.

Finally, the notion of relevance" from an IS perspective conjures ideas directly pertinent to the topics of avoidance and awakening. There is a notion in the hunter [with 


\section{DENIAL OF RELEVANCE}

a hunter-gatherer brain'] that something is lacking. In a very real sense we hunt and we forage for relevance" ( $\mathrm{O}^{`}$ Connor \& Copeland, 117). The hunt is the -search and gathering as the accumulation of information that, when applied, will bring one to some understanding or fulfillment "(Id.). Absent clarity or fulfillment in some area of life, anomalous states can be anything that we feel is missing from our knowledge stores" (122). The anomaly indicates that one has at least a very slight notion that something is lacking. One seeks to fill, or give meaning to, whatever this anomaly represents" (119). Therefore, the need for relevance leads hunter-gatherers searching for whatever could solve the problem" (118). Relevance is „what will answer the question... what may suggest a way of answering the question ... [or] what will help one formulate what may turn out to be the answer one seeks"" (Id.). Hence, - Carl Sagan notes that ancient Egyptians called the library _nourishment for the soul'; others talk about the flavors of relevance'; and still others pilgrimage toward feeding a spiritual hunger ... [that] provides sustenance for body, mind, and soul" (122-23, citations omitted). Notwithstanding these aforementioned issues are derived from an IS perspective, IS nevertheless eschews being pigeon-holed as soulless dullards" or ignoring the -design process through the image of a human heart" (105).

\section{Spiritual, Literary, \& Economic Information: The Walden Model}

A synthesis of information from various sources may yield identification, clarification, and better understanding of the penultimate human questions, as well as assisting information users across or through the information gap. In this instance, the question state or information gap is more richly and deeply understood by Thoreau's 


\section{DENIAL OF RELEVANCE}

quiet desperation" and Eliot"s life lost" and footfalls echo [past the misspent] rose garden."

Our understanding of what these are and how they occurred is benefited from notions about information-related behaviors of seeking, avoiding or denying, and the messy fumbling” (O‘Connor \& Copeland, 102), grappling” (100), juggling” (147), and -stumbling" (1) in our unawareness, expanded by increasing contributions from neuroscience. From this behavioral context, an interactive guidance or tutoring through information sources and questions assists in determining relevance to a user's specific question with specific priority for timely execution, moving from question to awareness or awakening. Cardinal John Henry Newman observed: And the disclosure of [Spirituality] is made [by] means of information...to individual minds...so that the truths of religion circulate through the world ...." Put simply, Spirituality is disclosed by information to minds of truths.

Awakening must per force occur amidst the anomalous state of pervasive ennui and prevalent malaise. In an April 20, 2011 survey, Young adults. . . fear graduation means tumbling into an economic black hole" (Cass, 8A). Another study found that the American dream of life getting better for each new generation feels like a myth to many of today‘s young adults" (Cass, 2011, April 19, 1A). One 23-year-old stated, I'm literally stuck, and there's nothing I can do about it" (Id., 7A). - Money troubles are steering the course of young lives" (Id.). At the other end of the age continuum, a recent report finds, In a bad economy where jobs are hard to come by for young, qualified workers, seniors face serious problems finding gainful employment [and] are more likely 


\section{DENIAL OF RELEVANCE}

than any other age group to face very long-term unemployment" (Mohajer, S.T., 2011, April 17).

Prior to 2011, Sanneh (2009, June 22) similarly noted that -arague sense of dissatisfaction with the demands and rewards of the modern economy is coalescing into something like a movement," away from -soul-destroying consequences in our new work habits — endless hours spent at flexible jobs, performing abstract tasks on computer screens." Yoshino (2009, June 2) described a backlash against corporate America by employees feeling a lost balance between work and life and that The rat race puts blinders on you and makes time fly." Similarly, Dreher (2009, May 31) wrote, Many a white-collar man works hard but lives in a world of soul-killing abstraction, where what he does, what he feels and who he is have little to do with one another .... The work cannot sustain him as a human being. Rather, it damages the best part of him, and it becomes imperative to partition work off from the rest of life."

Therefore, the quest for an answer" persists as famously if not sardonically put forth two millennia ago by the Roman governor Pontius Pilate: What is truth?” (John 18:38). Within time, truth is forever underway, always in motion and not final even in its most marvelous crystallizations" (Jaspers, K., 1952/1953, 104). Hence, humanity grapples, gropes, wrestles, and stumbles through time over the ultimate questions of life, death, meaning of existence, suffering, disasters, evil, unfairness, truth, justice, randomness, determinism, and purpose. This dialectic developed at least five major philosophical worldviews (with certain founders noted), and at least two significant evidentiary worldviews: existentialist (Kierkegaard, Nietzsche, Sartre), nihilist (Nietzsche), pragmatist (W. James), absurdist or paradoxical (Camus), and religious 


\section{DENIAL OF RELEVANCE}

(Moses, Buddha, Confucius, Jesus, Muhammad), coupled with -modern and postmodern modes of thought" (O`Connor \& Copeland, 97), respectively. These worldviews may overlap and merely constitute symbols or messages within which meaning may be captured.

The struggles underlying these worldviews strive to attain an awakening. As Orwell (1949) described it in 1984, Until they become conscious they will never rebel, and until after they have rebelled they cannot become conscious" (Part 1, chap. 7, 74). He continued, And the people under the sky were also very much the same ... people ignorant of one another's existence, held apart by walls of hatred and lies, and yet almost exactly the same - people who had never learned to think but ... would one day overturn the world" (Book 1, chap. 10). Thomas Jefferson (1816) similarly described this need for awakening: "If a nation expects to be ignorant and free in a state of civilization, it expects what never was and never will be." Others attribute further cautionary statements to Jefferson: - If we are to guard against ignorance and remain free, it is the responsibility of every American to be informed," and If ignorance is bliss, why aren't more people happy?" Or as G.K. Chesterton noted, A dead thing can go with the stream, but only a living thing can go against it." These sources demonstrate that a contemporary information need exists, also reflecting a common and ancient aspect of human nature, in search of a solution or awakening.

The religious (or spiritual) worldview may contribute to this search from ennui to awakening. Extending Darwin's thinking to contemporary views, our reptilian brains mapped to a mammalian metamorphosis and then into primates and resulting in hominids" (O‘Connor \& Copeland, 2003, 2, 10, 149). Whether through physical 


\section{DENIAL OF RELEVANCE}

evolution or cultural (Watts, 2002, 22, 86-88), humans“ evolved instincts seemingly thrived on fear and greed motives, contributing to the information gap of ennui or desperation. Religious texts recognized that the people are -weary, scattered, and confused" (Matthew 9:37), -stumbling” over laws and truths (Romans 9:32), and that now it is high time to awake out of sleep" (Romans 13:11). The religious worldview generally holds, though not exclusively from the others, three precepts common among the major world religions: transcendence (including religions focused on immanence over transcendence, yet transcendent as opposed to strict materialists), frugality or the deemphasis of consumption and material accumulation, and serving others.

First, contrary to the some nihilist, absurdist, or scientific materialist viewpoints, the religious worldview contends for the existence of something transcendent or a -something more." $\lceil\mathrm{T}]$ here must be something in reality that transcends physical determinism; otherwise thinking and choosing make no sense at all" (Daly \& Cobb, 1989/1994, 399). Tolstoy confronted his questions about life and any meaning by viewing all human knowledge" divided into two opposite hemispheres at the ends of which are two poles" of experimental science and of abstract science -at the extreme end of it stands metaphysics" (Tolstoy, 1882/1884, 16). H.G. Wells stated a different dichotomy: If God does not exist, nothing matters. If he does, nothing matters more.” G.K. Chesterton (1908) struck a familiar chord: Pragmatism is a matter of human needs; and one of the first human needs is to be something more than a pragmatist." And an atheist worldview recognizes this need, as A.C. Grayling asserted for his book, The Good Book-A Humanist Bible" (Ravitz, 2011): —thłunger for a 


\section{DENIAL OF RELEVANCE}

spiritual connection continues." This coincides with the information professional's notion of relevance in terms of that sense of lacking or for something more.

Second, the major religions urge appropriately dealing with money by proper stewardship of material needs and expenditures: No one can serve two masters . . . both God and Money" (Matthew 6:24). Thoreau questioned why people -everywhere" (4) were -serfs" who appeared - erushed and ... creeping down the road of life" (5) as a -slave and prisoner" in need of -self-emancipation" (7). He posited a formula: — theost of the thing is the amount of what I will call life which is to be exchanged for it" (25). Adam Smith agreed, What everything really costs to the man who wants to acquire it, is the toil and trouble of acquiring it" (Dupre \& Gagnier, 1996, 553). As a result, Thoreau found that by our pursuit of accumulation, comforts, and conveniences, humans render themselves — tapped," which is — th reason he is poor" (27). As G.K. Chesterton (1908) put it, When materialism leads men to complete fatalism (as it generally does), it is quite idle to pretend that it is in any sense a liberating force" (22). Chesterton further surmised, "There are two ways to get enough. One is to continue to accumulate more and more. The other is to desire less." Cardinal Newman found that humans -seem hardly to go by principle, but by what is merely expedient and convenient [rather than Jesus' description of the choice of two roads where] Narrow is the way" [which] is against the current of human feeling and opinion, and the course of the world" (Newman, 1868, 61, Daly \& Cobb, 380).

More recently, professors Daly and Cobb (1989/1994) stated, Shopping has become the great national pastime. ... Status attaches to finding unusual goods and unusual prices. Hence any move that threatens people in their role as consumers, even if 


\section{DENIAL OF RELEVANCE}

it does not deny them what they need in terms of goods, arouses considerable emotional hostility. It may make very difficult any discussion of how to deal with the national problem" of debt or squandered resources (373). That is, consumption arouses denial. Metropolitan Hilarion Alfeyev of Moscow, in a Dallas lecture of 13 February 2011 remarked that inhumanity" and -egocentrism have today reached truly universal dimension." People encounter the propaganda of consumerist's attitude to life ... on a daily basis ... [and] are taught that the only value in this life is material well-being and professional success." Instead, Thoreau in Walden proposed to be content with less" (29). It is the luxurious and dissipated who set the fashions which the herd so diligently follow ... But lo! Men have become the tools of their tools" (30). As Thoreau resisted bowing to the pressures by which humans become the controlled tool, Flannery O'Connor charged readers to — push bak against the age as hard as it pushes against you" (Dreher, 2008, October 26, 1P).

Third, religious worldviews advocate serving others. An important result of Thoreau's frugal and conservationist perspective of Walden is that time, money, and other resources are freed up to solve problems and assist others. Daly and Cobb (1994) adopted this Thoreauvian principle:

On the basis of massive borrowing and massive sales of national assets, Americans have been squandering their heritage and impoverishing their children. They have done so for the sake of present consumption, the enjoyment of the shopping that accompanies it. ... (373).

Change - will depend on finding images with mass appeal that show why the current affluence is an illusion" (373), which I propose will occur due to the -stories" (Dreher, 


\section{DENIAL OF RELEVANCE}

2011, April 24, 6P) by mentors and tutors. $[\mathrm{T}]$ he real possibility for change depends on an awakening of the religious depths in a world whose secularity has gone quite stale ... . Overcoming ['misplaced concreteness [which] brought us to the present crisis'] is a religious task" (Daly \& Cobb, 380-381). But if service to others is ignored through current consumption, Perhaps [_ourchildren's children'] will learn also to forgive this generation its blind commitment to ever greater consumption" (Daly \& Cobb, 406). Cardinal Newman (1868) also described his generation «nder a considerable danger at this day ... of self-deception, of being asleep while they think themselves awake," and thereby -cheated of the Truth" (63). He too adopted the prescriptions of

Thoreau, Daly, and Cobb, to do with less and reduce consumption as a form of self-denial supported by the religious texts of Mark 8:34 and Luke 9:23, admonishing to - dey himself, and take up his cross" $(65,67)$. Thus, the religious worldview proffers an informational model from —quitedesperation" into the awareness of our rose garden" and eastles in the air." This model consists of these three precepts, with an economic framework for valuing life in terms of spending, consumption, and labor.

\section{Conclusions}

In the face of saturnine prospects, gaining -spiritual knowledge" parallels, encapsulates, and overlays the weaving of threads from seemingly unrelated disciplines into a tapestry to bridge information gaps. Religion and IS share a natural, almost symbiotic, fit to aid humanity on questions of greatest magnitude, depth, and complexity. They can be mutually and reciprocally beneficial, borrowing from disparate disciplines to evoke an awakening event, because we -eannot anticipate" ( $\mathrm{O}^{‘}$ Connor \& Copeland, 11) the catalyst for awareness. Indeed, the interdisciplinary nature of IS itself contributes to 


\section{DENIAL OF RELEVANCE}

the core ambition of religion to awaken an individual or a community, essential in resolving information needs as a Buddha" (which means —waken” or -nlighten”).

Samuels, an arguably modern Thoreau (also a single, male, Harvard graduate), wrote the following in his mid- to late-30's, of postmodern ennui in the October 17, 1999 The New York Times Magazine:

Our inability to imagine a future together was not ours alone. It was a symptom of a larger fracture or collapse, involving however many hundreds of thousands of people in their 20's and early $30^{\prime}$ s who seemed to lack any sense of necessary connection to anything larger than their own narrowly personal aims and preoccupations ... . [and] the most profound of dissatisfactions: ourselves .... . What is so new and radical about the present epidemic of selfishness is how widely, and unthinkingly, it is shared .... The self is the root of selfishness, and selfishness is what makes us unhappy. Too much concentration on ourselves makes us anxious, because the self cannot support the weight. That is the difference between the self and the soul.

Samuels thus confirms Thoreau's -desperation" and places it in modern culture. Yet Alice Walker‘s Pulitzer Prize-winning novel, —Tł Color Purple” (1982/1992), conjures religion and IS concepts as a solution: But only them that search for it inside find it. And sometimes it just manifest itself even if you not looking, or don't know what you looking for .... Now that my eyes opening, I feels like a fool .... You have to git man off your eyeball, before you can see anything a'tall" (195, 197, Colossians 3:1).

Information professionals may assist users in moving from avoidance to -eyeopening" awakening, thereby joining Robert Frost (1916) on the divergences encountered in life choices when he took the one less traveled by, And that has made all the difference." And then to crow with Thoreau, - Fo be awake is to be alive" (74), to build -astles in the air," and to put — fundations under them" so — thaif one advances 


\section{DENIAL OF RELEVANCE}

confidently in the direction of his dreams, and endeavors to live the life which he has imagined, he will meet with a success unexpected in common hours" (267).

\section{Author Note}

Van VanBebber, JD, MS, CPA, a PhD student (ABD) at the University of North Texas, focuses on socioeconomic and philosophic issues. He previously practiced law for 15 years at major Dallas law firms, and earlier as a CPA at PriceWaterhouse. He graduated with Stone Scholar honors from Columbia Law School, after ranking first, summa cum laude from UNT, with bachelor and master's degrees in accounting. He has received leadership awards from the Dallas Bar Association, published in the Wall Street Journal, the National Law Journal, and the Dallas Morning News, and had an academic paper presented in Shanghai, China.

\section{References}

Alfeyev, H., Archbishop Rev. Metropolitan (2011, February 13). No one has ever seen God. Lecture at Highland Park Presbyterian Church, Dallas, TX.

Allen, B.L. (1996). Information tasks: Toward a user-centered approach to information systems. San Diego, CA: Academic Press.

Bates, M.J. (1999). The invisible substrate of information science. Journal of the American Society for Information Science, 50(12), 1043-1050.

Brooks, D. (2011, March 13). Expect a big cultural change to hit soon. Dallas Morning News, 4P.

Bush, V. (1945). As We May Think. The Atlantic Online, 12 pp., Retrieved from www.theatlantic.com, on June 23, 2009.

Case, D.O. (2002/2007). Looking for information: A survey of research on information seeking, needs, and behavior ( $2^{\text {nd }}$ ed.). New York: Academic.

Case, D.O., Andrews, J.E., Johnson, J.D., \& Allard, S.L. (2005). Avoiding versus seeking: The relationship of information seeking to avoidance, blunting, coping, dissonance, and related concepts. Journal of the Medical Library Association, 93(3), 353-362. 


\section{DENIAL OF RELEVANCE}

Cass, C. (2011, April 20). Young adults not high on high schools. Dallas Morning News, 8A.

Cass, C. (2011, April 19). Young adults resigned to tougher finances. Dallas Morning News, 1A, 7A.

Chesterton, G.K. (1908). Orthodoxy. New York: Dodd, Mead \& Co.

Churchland, P.M. (1995). The Engine of Reason, the Seat of the Soul: A Philosophical Journey into the Brain. Cambridge, Mass: MIT Press.

Daly, H.E., \& Cobb, Jr., J.B. (1989/1994). For The Common Good: Redirecting the Economy toward Community, the Environment, and a Sustainable Future $\left(2^{\text {nd }}\right.$ Ed.). Boston: Beacon Press.

Dreher, R. (2008, October 26). Wendell Berry‘s time is now. Dallas Morning News, 1P.

Dreher, R. (2009, May 31). The soft bigotry of high expectations. Dallas Morning News, $4 \mathrm{P}$.

Dreher, R. (2011, April 24). Reliving the sacrifice of Christ. Dallas Morning News, 6P.

Dupre, J. and Gagnier, R. (1996, June). A Brief History of Work. Journal of Economic Issues, $X X X(2), 553-559$.

Eliot, T.S. (1934). The Rock. London: Faber \& Faber.

Eliot, T.S. (1962). T.S. Eliot: a collection of critical essays, 1962(1). New Jersey: Prentice-Hall.

Frost, R. (1916). The Road Not Taken. Mountain Interval. Henry Holt \& Company.

Gilbert, T. (1978/1996). Human Competence: Engineering Worthy Performance. Massachusetts: HRD Press, Inc.

Jaspers, K. (1953). Tragedy Is Not Enough. Boston: Beacon Press.

Jefferson, T. (1816, January 6). Letter to Charles Yancey.

Mohajer, S.T. (2011, April 17). Job cuts for poor seniors could up homelessness. Associated Press. Retrieved April 18, 2011.

Newman, J.H. (1868). Parochial and Plain Sermons, vol. 1 (1825-1843). London: Rivingtons. 


\section{DENIAL OF RELEVANCE}

O‘Connor, B., Copeland, J.H., with Kearns, J. (2003). Hunting and Gathering on the Information Savanna: Conversations on Modeling Human Search Abilities. Lanham, MD: Scarecrow Press, Inc.

O‘Connor, B., Kearns, J., and Anderson, R.L. (2008). Doing Things with Information: Beyond Indexing and Abstracting. Westport, CT: Libraries Unlimited.

Orwell, G. (1949). 1984. London: Secker and Warburg.

Ravitz, J. (2011, April 11). Leading atheist publishes secular Bible. CNN.com. Retrieved April 25, 2011.

Samuels, D. (1999, October 17). In the age of radical selfishness. The New York Times Magazine.

Sanneh, K. (2009, June 22). Out Of The Office: Fast bikes, slow food, and the workplace wars. The New Yorker. Retrieved June 23, 2009, from www.newyorker.com/arts/critics/atlarge/2009/06/22/.

Saracevic, T. (1999). Information Science. Journal of the American Society for Information Science, 50(12), 1051-1063.

Thoreau, H.D. (1854/1992). Walden. New York: Marboro Books Corp., a division of Barnes \& Noble Books.

Tolstoy, L.N. (1882/1884). A Confession.

Walker, A. (1982/1992). The Color Purple. New York: Harcourt, Inc.

Watts, F. (2002). Theology and Psychology. Aldershot, England: Ashgate Publishing Limited.

Wilson, P. (1973). Situational Relevance. Information Storage Retrieval, 9, 457-471.

Wilson, P. (1977). Public Knowledge, Private Ignorance: Toward a Library and Information Policy. Contributions in Librarianship and Information Science, no. 10. Westport, CT: Greenwood Press.

Yoshino, K. (2009, June7). Laid off - and loving it. Dallas Morning News, 6D. 